\title{
Past and future challenges in managing European seas
}

\author{
Thorsten Blenckner $^{1}$, Andreas Kannen ${ }^{2}$, Alberto Barausse ${ }^{3}$, Christian Fischer $^{2}$, Johanna J. Heymans ${ }^{4}$, Tiziana Luisetti ${ }^{5}$, Valentin \\ Todorova ${ }^{6}$, Matilda Valman ${ }^{1}$ and Laurence Mee ${ }^{4}$
}

\begin{abstract}
Marine environments have undergone large-scale changes in recent decades as a result of multiple anthropogenic pressures, such as overfishing, eutrophication, habitat fragmentation, etc., causing often nonlinear ecosystem responses. At the same time, management institutions lack the appropriate measures to address these abrupt transformations. We focus on existing examples from social-ecological systems of European seas that can be used to inform and advise future management. Examples from the Black Sea and the Baltic Sea on long-term ecosystem changes caused by eutrophication and fisheries, as well as changes in management institutions, illustrate nonlinear dynamics in social-ecological systems. Furthermore, we present two major future challenges, i.e., climate change and energy intensification, that could further increase the potential for nonlinear changes in the near future. Practical tools to address these challenges are presented, such as ensuring learning, flexibility, and networking in decision-making processes across sectors and scales. A combination of risk analysis with a scenario-planning approach might help to identify the risks of ecosystem changes early on and may frame societal changes to inform decision-making structures to proactively prevent drastic surprises in European seas.
\end{abstract}

Key Words: ecosystem-based management; regime shifts; scenarios

\section{INTRODUCTION}

Marine environments have undergone large-scale changes during the past decades because of multiple anthropogenic impacts, such as overfishing, eutrophication, habitat fragmentation, etc. Often the ecosystem response to these multiple pressures is nonlinear, which may lead to unexpected behavior by the ecological system (deYoung et al. 2008) and to sudden, ecosystem-wide shifts, i.e., regime shifts (Francis et al. 1998, Lees et al. 2006, Beaugrand et al. 2008, Kirby et al. 2009, Alheit and Bakun 2010). There is little doubt that, in the future, the pressure on marine systems may increase due to acceleration of climate-induced changes thatsynergistically to other human and natural processes-affect the ecosystem dynamics, with major consequences for the provision of ecosystem services (Philippart et al. 2011). To prevent regime shifts, with resulting disruptions of ecosystem services in the future, an adaptive ecosystem-based management (EBM) framework has been proposed (Folke et al. 2004). For European seas, the Marine Strategy Framework Directive (MSFD) is aimed at implementing such an approach. The MSFD requires member states to achieve "good environmental status" (GES) for their marine waters by 2020. According to Article 3(5), GES means "the environmental status of marine waters where these provide ecologically diverse and dynamic oceans and seas which are clean, healthy and productive within their intrinsic conditions, and the use of the marine environment is at a level that is sustainable, thus safeguarding the potential for uses and activities by current and future generations." Good environmental status is to be achieved using adaptive management on the basis of an ecosystem approach (Article 3, paragraph 5). Farmer et al. (2012) define an ecosystem approach as resource planning and management that integrates the connections among land, air, and water and all living things, including people, their activities, and institutions. At the heart of current environmental debate is a trade-off between the often short-term benefits of drawing down natural capital for economic and social development and the more longterm benefits of maintaining resilient marine social-ecological systems (SES).
In this perspective, it is important to have information available that warns the manager of potential ecological regime shifts. One approach is the development of early warning indicators, which have been proposed to provide information about the risk of a regime shift in the near future (Scheffer et al. 2009). This interesting approach has been tested on many ecosystems but requires a high temporal or spatial resolution of monitoring data, a prerequisite that is seldom realized in marine ecosystems (Lindegren et al. 2012). An alternative approach in EBM may be to build a high resilience to prevent abrupt changes and ecosystem-wide regime shifts. It is important to note that the resilience of a current undesirable ecosystem state might be high due to ecological feedbacks that reinforce the degraded state (Scheffer et al. 2001). In this situation, management needs to steer the system in a direction that will break these feedbacks to achieve a good environmental status (Nyström et al. 2012). A further advantage of a highly resilient system is that the changes are not drastic, and future states may therefore be easier to forecast, particularly important for fisheries that benefit from more predictable fish stocks (Stenseth and Rouyer 2008).

Here, we will provide some information of how the existing experiences from the social-ecological system of the European seas can be used to inform and advise future management. We will provide first some social-ecological examples that have been observed in European seas. Then, we discuss future challenges, including potential nonlinear responses that can be expected to affect marine ecosystems and ecosystem-based management. Finally, we offer some approaches that can help in steering future marine ecosystem management.

\section{EXAMPLES OF PAST NONLINEARITIES}

There are several examples of nonlinear system changes reported in literature (Hare and Mantua 2000, Heymans et al. 2007, deYoung 2008, Kenny et al. 2009). Here, we discuss two examples from the past with impacts relevant for today and in the future. One example refers to ecosystem changes due to human interaction from the Black Sea. The second example focuses on

\footnotetext{
${ }^{1}$ Stockholm Resilience Centre, Stockholm University, ${ }^{2}$ Institute for Coastal Research, Human Dimensions in Coastal Areas, ${ }^{3}$ University of Padova, ${ }^{4}$ Scottish Association for Marine Science, Scottish Marine Institute, ${ }^{5}$ Centre for Social and Economic Research on the Global Environment (CSERGE), School of Environmental Sciences, University of East Anglia, ${ }^{6}$ Institute of Oceanology, Bulgarian Academy of Sciences
} 
a nonlinear change in the institutional setting in HELCOM, illustrating the relevance of changes in ecosystem management structures due to political change.

\section{Eutrophication and fisheries in the Black Sea}

Loss of resilience and nonlinear ecosystem responses are described in both the benthic and the pelagic systems of the Black Sea. In Mee et al. (2005), a simple conceptual model illustrates the nonlinear response of the Black Sea benthic system to eutrophication. Initial pristine conditions consist of a phytobenthos-dominated benthic system, with a high nutrient assimilation potential, a net oxygen production by the algae, and a high filtering capacity of bivalves. The ecosystem crossed a critical threshold (threshold 1), at which algal beds become shaded by the increased water-column phytoplankton, and the algal beds collapse. The system transforms into a bivalvedominated benthic regime. The bivalve community is able to cope with excessive food supply and buffer eutrophication until heavy blooms and detritus create a large oxygen demand, leading to large anoxic sea floors. Under these hypoxic conditions, mussels close and may ultimately die and their filtering capacity is lost (threshold 2), leading to a regime where the benthic system collapses. The degraded regime is characterized by massive development of endobenthic organisms (species that live buried, or burrowing in the sediment), accompanied by a significant decrease in epibenthic species (crustaceans and mollusks). The system may exhibit hysteresis, i.e., changes in internal feedbacks stabilize a state so that extra effort is needed to bring the ecosystem back to its prechange state (Scheffer et al. 2001), or even irreversibility when the human pressure is removed (Mee et al. 2005), especially when available niches are occupied by invasive species.

The pelagic ecosystem of the Black Sea underwent major regime shifts, occurring first because of overfishing of top predators and middle trophic levels, causing system-wide trophic cascades (Daskalov et al. 2007). The overfishing of the pelagic top predators in the 1970s and of planktivorous fish in the 1990s resulted in regime shifts and caused changes in the abundance of the zooplankton, jellyfish, and phytoplankton, as well as in surface oxygen and phosphate concentrations. Llope et al. (2011) identified the removal of top predators as a key element in terms of loss of resilience that inevitably leads to reorganization of the food web. Historically, the fishery-driven trophic cascade first disturbed the structure of the system from higher trophic levels and then the already disturbed food web was further degraded by eutrophication. Simulation results demonstrated that increased productivity could have been more efficiently handled by a more complex ecosystem including viable top predators (Llope et al. 2011). For that reason, a regeneration of the food web structure by rebuilding the top predator stocks could improve the system's ability to counterbalance fluctuations driven by climate or eutrophication.

Interestingly, initial recovery of the Black Sea ecosystem, i.e., the reduction of the anoxic "dead zone" on the northwest shelf, resulted from a collapse in the social and economic system in formerly centrally planned economies of the Soviet Union and Warsaw Pact. The economic and political collapse led to undesirable step changes in the social system (including birth rate and life expectancy) but also in the ability of farmers to obtain fertilizers or to maintain huge formerly state-owned intensive animal breeding units. This reduced the nutrient load to the Black Sea, which, however, did not recover fully, partly because fishing pressure (largely by Turkey, unaffected by the sociopolitical crisis) was maintained. Without a complete reorganization of the regional social system (through effective agreements), recognizing the need for joint fisheries management and marine protected areas, further ecological improvements are unlikely. However, transnational governance structures, which could approach such problems, are weak in the Black Sea compared with, for example, the Baltic. Although new institutions, in particular the Black Sea Commission, came into being and have been supported by the European Union (EU) and the United Nations (UN), these are constrained in terms of actions and political influence by political problems between member states. Indeed, a new push for agricultural development without sufficient measures to limit nutrient inputs could return the system to its collapsed resilient state (Mee 2006, Langmead et al. 2009).

\section{Changes in HELCOM and Baltic Sea transnational structures after 1990}

The Baltic Marine Environment Protection Commission (Helsinki Commission, HELCOM) has formed a platform for intergovernmental collaboration between the Baltic Sea states since its foundation in 1974. HELCOM functions as the governing body of the Helsinki Convention. The contracting parties to the 1974 convention were Denmark, Finland, the German Democratic Republic, the Federal Republic of Germany, the Polish People's Republic, Sweden, and the Union of Soviet Socialist Republics.

Since its inception, HELCOM has been recognized for its remarkable institutional stability. Change occurs gradually where new ideas are layered upon preexisting structures (Valman 2013). However, due to rapid changes in the geopolitical landscape caused by the fall of the Iron Curtain, the reunification of Germany, and the dissolution of the Soviet Union, the Helsinki Convention needed to be revised. A new Convention was signed in 1992 by Denmark, Estonia, the European Community (EC), Finland, Germany, Latvia, Lithuania, Poland, Russia, and Sweden (Fitzmaurice 1993, Poutanen 1996).

The need for a revision of the Helsinki Convention due to formation of new states and new state borders also opened a window of opportunity to revise some of the drawbacks of the old Convention. For example, before 1992, internal waters and the states' territorial seas were not part of HELCOM. However, when addressing land-based pollution and eutrophication, the sources are in internal waters and along rivers. Therefore, a breakthrough in the new 1992 Convention was to include all internal waters. This change enabled the new Convention for the first time to address land-based pollution and the introduction of new paradigms and principles, such as the term "ecosystem" (ecosystem-based management was then subsequently defined together with the Oslo-Paris Conventions, OSPAR, in 2003), the polluter pays principle, and the use of "best environmental practice" and "best available technology."

In terms of action, the 1992 Convention paved the way for the Joint Comprehensive Environmental Action Programme (JCP). This program was signed at the same Ministerial meeting as the 
revision of the Convention and set out to control pollution from so-called "hotspots." Hotspots had been identified as point sources of pollution from, e.g., municipal facilities and industrial plants, agricultural areas. The list of hotspots was continuously reviewed and revised, with the final goal, the elimination of all hotspots, to be completed by 2012 (108 out of 162 hotspots were eliminated in June 2012; Berbalk 1996, Helsinki Commission 2013).

\section{FUTURE TRENDS AND POTENTIAL PATHWAYS}

In the previous section, we looked into environmental and institutional changes in the past, illustrating that both systems experience sudden change. However, in a dynamic world, new challenges constantly emerge within the panarchy of systems, i.e., interlinked system elements change in continual adaptive cycles of growth, accumulation, restructuring, and renewal (Gunderson and Holling 2002) and can be expected to affect marine ecosystems and ecosystem management. There are currently at least two major management challenges facing Europe's regional seas, which are considered in detail in the following two sections.

\section{Future climate change}

Interannual variation in climate and climate change affect marine ecosystems by, e.g., the poleward species range expansions, changes in local species compositions due to physiological intolerance to new conditions (e.g., a shift from marine to brackish or freshwater species with decreasing salinities) and arrival of nonindigenous species, observed across a large number of marine ecosystems (Beaugrand et al. 2002, Drinkwater 2002, Daskalov et al. 2007, Drinkwater et al. 2010). However, more specific changes in climate conditions and, consequently, in the marine environment are often largely determined by the location and general characteristics of the sea (Philippart et al. 2011). In Europe, for example, warming has primarily been higher in the northern and enclosed seas than in the southern or open ones (Belkin 2009).

Future climate projections indicate sea-surface temperature increases from 1 to 4 degrees Celsius (in some extreme cases, even 7 degrees), with large spatial variation (for an overview, see Philippart et al. 2011). Besides temperature-induced changes, salinity in semienclosed seas, like the Baltic Sea, can be of major importance for species distribution. Meier et al. (2012) projected a significant lower salinity and deep-water oxygen concentrations until 2100, which may lead to a shift from marine to more brackish or even freshwater species, negatively affecting the abundance of commercially important fish species, such as cod (Niiranen et al. 2013). Also, in the Mediterranean and Black Seas, endemic species may disappear, and there is a high risk that associated niches will probably be filled by species originating from adjacent waters (Philippart et al. 2011). Occupation of niches tends to be nonlinear, as illustrated by the massive arrival of the comb jelly, Mnemiopsis leidyi, in the Black Sea or the spread of the invasive algae, Caulerpa taxifolia, in the Mediterranean, both in the early 1990s. Climate change may suddenly make such invasions viable; for example, the Pacific oyster, Crassostrea gigas, was cultured in northern Europe on the assumption that the water was too cold for it to propagate. This assumption was invalidated by climate change, and the species is spreading in the Wadden Sea and other areas, where it is fundamentally transforming the ecosystem (Diederich et al. 2004).

\section{Use intensification of energy}

A significant trend toward an increase in number and intensity of human activities in marine areas can be observed, also by a growing set of policies and economic incentives. For example, the European Commission recently released its proposal for a directive on maritime spatial planning (MSP) and coastal management (COM 2013). The COM explicitly names a number of sea uses to be recognized in MSP and emphasizes the contribution of marine areas to economic growth: namely, the promotion of maritime transport, development of renewable energies, and growth of the fisheries and aquaculture sectors.

Renewable energies are one of the most significant drivers affecting marine systems, particularly in the North Sea (Kannen 2014), but also on the West Coast of Scotland.

The move toward renewable energy is partly a response to global climate change (Wiser et al. 2011), thus demonstrating the interconnectedness between climate change and its societal adaptation. Although large-scale offshore carbon capture and storage (CCS) developments, tidal, wave, and osmotic energy production are still at the pilot project stage, the offshore wind farm sector has already become a significant part of energy politics, and several sites have become operational. In all North Sea countries, installation plans of offshore wind farms exist. For example, the largest developments currently planned are in the UK territorial area of the Dogger Bank, with an agreed size of 9 GW until 2020, and in Germany, with an expected capacity of 20-25 GW by 2030, covering an estimated sea area of 2000-4000 $\mathrm{km}^{2}$ (Bundesministerium für Umwelt, Naturschutz und Reaktorsicherheit (BMU) 2002). These numbers demonstrate that a significant amount of marine space could be turned into wind farm sites in the next 20 years. Shipping, fisheries, and birds are particularly affected by the construction of offshore wind farms. This is of importance as "the North Sea has some of the busiest shipping lanes in the world and maritime transport continues to increase" (OSPAR 2010: 154). For fisheries, Berkenhagen et al. (2010) concluded that more than $50 \%$ of sole catches in the German North Sea come from areas for which wind farms are planned. In these two cases, spatial planning and analysis of economic trade-offs might provide solutions, but only if long-term as well as short-term costs and benefits are considered. Ecological impacts of offshore wind farms, in particular on marine mammals and birds, are related as well to cumulative effects of a large set of wind farms (Busch et al. 2013), or even to combined effects of wind farms and shipping (Garthe and Mendel 2010), but are poorly understood. As these examples show, the cumulative and interacting effect of drivers might significantly increase the risk for nonlinear and unexpected system changes in the future. In addition, the social structure of the local society might affect the social impact that marine renewable energy will have on the area (Alexander et al. 2013).

\section{TOOLS FOR PREPARING FOR THE FUTURE}

In the following section, we will discuss different approaches and tools that can help anticipate or avert nonlinear changes and surprises in marine ecosystems. In particular, we will elaborate on adaptive marine planning with stakeholder participation and on scenario planning as an explorative tool.

\section{Dealing with nonlinearities and uncertainty in planning and management}

In the context of the adaptive approach for management (Mee 2005, Mee et al. 2008), now incorporated in the MSFD, one practical way of dealing with uncertainties and nonlinearities is 
to ensure learning, flexibility, and networking in decision-making processes. This not only includes information exchange and collaboration across sectors but also across scales.

The example of use intensification and emergence of new uses, such as marine renewables development discussed above, not only shows areas of risk for nonlinear unintended impacts from single activities but also the cumulative impacts of an increasingly complex pattern of many activities (see also Kannen et al. 2010, Kannen 2014). The risk may originate from many individual decisions at national or even subnational scales. This is what Swaney et al. (2012) have called the "tyranny of small decisions."

The regional sea conventions are one way to promote transnational cooperation and planning as a step toward the development of more coherent policies at the level of large ecosystems. However, conventions such as OSPAR for the NorthEast Atlantic and HELCOM for the Baltic focus on wellestablished environmental issues. They often lack mechanisms to deal with seas serving multiple functions for society, functions that are perceived differently by the diverse actors and societal groups and between different countries (Kannen 2014). van Tatenhove (2013) proposes developing more integrated governance arrangements for European seas along several building blocks, recognizing the currently fragmented and sometimes conflicting patchwork of maritime policies in Europe (in particular the MSFD, the MSP, and the coastal zone management (CZM) directive, and the integrated maritime policy. Such "institution building," which does not necessarily mean new organizations, but change in existing arrangements and institutional settings is in itself a nonlinear process in many cases, as the example from HELCOM indicates. A positive example for an institution successfully undergoing continuous evolution is illustrated by the Trilateral Wadden Sea Cooperation (TWSC, analyzed by Fischer 2011). This analysis also revealed some success factors for the cooperation in the TWSC (Kannen et al. 2012):

- common and shared interests;

- a physically available coordination office with long-term staff members to generate trust and provide organizational support;

- limited group size (in the case of TWSC, three member states);

- legally nonbinding cooperation to support flexible solutions in the sense that individual parties can decide in each case to join the common way or not;

- use of informal structures to derive more flexibility and openness for new issues;

- thematic and spatial identity among the actors, both of which are linked to a degree of emotional identity and motivate cooperation toward common goals.

With these experiences, adaptive management first deals with communication processes not only to inform but also to enable and stimulate collaborative learning among actors, including scientific and nonscientific (e.g., local knowledge) information, and different problem frames of relevant societal groups (Kannen 2014). Learning for adaptive management also relies on continuous improvement and evolvement of the information base, including monitoring of changes in ecosystem status and socioeconomic change in order to understand the development of potential shifts in social-ecological interactions. It also relies on the ability to set realistic goals. The scientist-stakeholder dialog should be facilitated in a way that manages expectations, particularly in systems such as the southern North Sea that have already experienced change that is difficult to reverse (Gilbert et al. 2014).

The approach outlined above relies heavily on participation of all actors and stakeholders in the communication and learning process. Increasing stakeholder participation in the management of natural resources is regarded as inherently desirable by many authors (e.g., Garcia and Cochrane 2005, Walker et al. 2002, Pomeroy and Douvere 2008, Carollo and Reed 2010) and has been demonstrated to enhance the quality of decisions (e.g., Brody 2003, Koontz and Johnson 2004).

In general, policy makers have to justify and account for their decisions to other actors that are directly or indirectly affected by their decisions. With planning, however, many decisions are effectively irreversible; the huge investment in establishing a windfarm is unlikely to be reversed after a 5-year term of office! On the other hand, the intention to designate the Eratosthenes seamount near Cyprus as a marine protected area (Hoyt 2011) was swept aside following the 2013 financial crisis in the country and the realization that concessions for oil and gas reserves in the area could provide some economic relief. Such asymmetries in commitment can undermine resilience and make the aspirations of adaptive management challenging.

Several issues of quality assurance to secure accountability in planning and decision making for coastal and marine environments have been discussed in International Council for the Exploration of the Sea (ICES) (2012). In this report, the planning process is composed of multiple steps, each requiring aspects of decision making, peer review, consultation, communication, and validation. Quality assurance elements refer to the usability of data and scientific advice, the input from stakeholder perspectives and advice, as well as policy formulation. Structured quality assurance concepts provide some level of assurance that the resulting plan will have high acceptability among regulators, stakeholders, and the public. Adequate enforcement measures are needed to ensure that the plan is implementable from the perspective of the effectiveness and feasibility of the management measures, together with guarantees of transparency and traceability.

\section{Scenarios, learning, and resilience}

A large part of current planning and modeling is based upon the notion of a world in equilibrium, predominantly governed by linear or predictable cause-effect relationships. It is particularly difficult to explore the potential consequences of human social and economic drivers on marine systems, but a scenario analysis can be applied, ranging from impact assessment of certain developments to providing a decision support system assessing potential future development for politicians and decision makers (e.g., World Business Council for Sustainable Development (WBCSD) 1997, Raskin et al. 1998, Intergovernmental Panel on Climate Change (IPCC) 2000, Rotmans et al. 2001, Shell 2002, Millennium Ecosystem Assessment 2003, Meier et al. 2012). 
Examples where scenarios have been used to analyze conditions for different development pathways of offshore wind energy along the German North Sea coast (Kannen et al. 2009) or used by the trilateral Wadden Sea Forum (Wadden Sea Forum 2006) to develop a common vision and joint activity targets among a wide range of governmental and nongovernmental stakeholders, exist. The scenario approach in general can therefore aid the development of long-term visions for coastal and marine areas and contribute to consensus-oriented management (Glaeser et al. 2005).

At a European regional seas scale, Langmead et al. (2009) applied scenarios to model the potential environmental consequences of changes in social and economic drivers in the 16-country Black Sea basin. (Five different sociopolitical scenarios were modeled, most of which projected an increase in nutrient loads to the Sea and a return of the "dead zone" unless explicit actions were taken to curb them and to correct current overfishing. Recent data used in KnowSeas (Friedrich, personal communication) suggest that the northwest shelf of the Black Sea has areas of hypoxia once again, and this demonstrates the usefulness of the approach.

Another example from the North Sea (Heymans et al. 2011) indicates the possible trade-offs between a future focused on maximizing the profitability of fisheries vs. a future pursuing a vision of a more "resilient" ecosystem with more long-lived species. The study found that a totally different fleet structure would be needed to achieve these scenarios and that there would be major effects on the overall redundancy in the ecosystem. The study further revealed that, by increasing the fishing effort, subsidies have a negative effect on the profitability of fisheries and the underlying supporting ecosystem. Removing fishing subsidies might therefore be a viable management strategy that would increase the overall resilience of the system and the profitability of the fisheries.

\section{BUILDING MORE RESILIENT SOCIAL-ECOLOGICAL SYSTEMS IN EUROPE'S SEAS}

Much of our discussion has focused on the role of the MSFD in moving toward GES in Europe's Seas. However, this legislation, although innovative, largely responds to the adverse implications of environmental pressure on individual ecosystem components and is reactive rather than proactive. Furthermore, the use of marine systems is the domain of the integrated maritime policy of the EU (common fisheries policies; CFP) and a myriad of initiatives by member states within their territorial waters and their exclusive economic zones (EEZ). Some policy statements have attempted to correct this imbalance. The green paper on the reform of the CFP (Commission of the European Communities (CEC) 2009), for example, declares that "Ecological sustainability is a basic premise for the future of European Fisheries." Largely, however, economic development is tensioned against its environmental impacts, rather than trying to optimize economic and environmental potential in tandem from the outset, as the ecosystem approach would imply. The experiences we outlined before, on past changes as well as future challenges, suggest a more proactive and inclusive planning and management approach, and the tools we discussed provide mechanisms to move in this direction. Moving toward a fully integrated approach could allow SES resilience to be taken seriously as a factor underpinning decision making. Tools such as scenario development and modeling would play a greater part in planning, just as originally suggested by Holling (1978) when he developed the concept of adaptive management. Assessment of the capacity of the system to deliver ecosystem services without exceeding thresholds should be a critical component in planning (see Cormier et al. 2013 for implementing a structured risk-based approach in this direction), as should assessment of the sociopolitical system for governing and complying with agreed policies. A combination of risk analysis with a forward-looking scenario approach might help to identify the risks of ecosystem changes, such as discussed for the Black Sea, early on and frame societal changes in order to inform decision-making structures, which follow adaptive and learningbased approaches as outlined before. However, as discussed before and shown for the Baltic, this also depends on the institutional system and its constituents. Here, we face the reality that, with political attention directed toward economic growth as a remedy for the current financial crisis, social-ecological system resilience is difficult to prioritize. The financial crisis and global recession may have started a vicious circle in which further degradation of ecosystem services due to accelerated short-term exploitation may lead to an even worse global crisis and depletion of resources. On the other hand, development of regional cooperation mechanisms might help determine appropriate reaction and identify solutions at regional sea scales, as the example of HELCOM illustrates. In particular, this might be necessary for renewable energies from the sea (wind, wave, tidal) and related implications on marine systems. One example of cooperation in this context is the BaltSeaPlan Vision 2030 for Baltic Sea MSP (Gee et al. 2011). The need to agree on basic principles for enhancing the resilience of ecosystem services has also become part of the climate change narrative, particularly because of the trade-offs between ecosystem services at different scales (Biggs et al. 2012). Furthermore, the mix of ecosystem services society considers will change in the future with changing societal values and preferences. Such thinking has yet to become a significant and explicit part of the debate on how best to manage marine systems. Consideration of the role of democracy, human rights, and capacity building to enhance the socioeconomic resilience of a country could also play a part in the development of a regional and global vision for optimizing socioeconomic development within resilient ecological systems in Europe and beyond.

Responses to this article can be read online at: http://www.ecologyandsociety.org/issues/responses. $\mathrm{php} / 7246$

\footnotetext{
Acknowledgments:

The authors wish to express their great sadness at the tragic and sudden death of Professor Laurence Mee. This study was funded by grants from the EC FP7 project: Knowledge-based Sustainable Management for Europe's Seas (KnowSeas, Grant agreement no. 226675), the strategic program at Stockholm University "Baltic Ecosystem Adaptive Management Program". Research presented in this paper contributes to the Nordic Centre for Research on Marine Ecosystems and Resources under Climate Change (NorMER), which is funded by the Norden Top-level Research Initiative sub-programme 'Effect Studies and Adaptation to Climate Change'.
} 


\section{LITERATURE CITED}

Alexander K. A., T. A. Wilding, and J. J. Heymans. 2013. Attitudes of Scottish fishers towards marine renewable energy. Marine Policy 37: 239-244.

Alheit J., and A. Bakun. 2010. Population synchronies within and between ocean basins: apparent teleconnections and implications as to physical-biological linkage mechanisms. Journal of Marine Systems 79: 267-285.

Beaugrand G., M. Edwards, K. Brander, C. Luczak, and F. Ibanez. 2008. Causes and projections of abrupt climate-driven ecosystem shifts in the North Atlantic. Ecology Letters 11:11571168.

Beaugrand, G., P. C. Reid, F. Ibanez, and M. Edwards. 2002. Reorganization of North Atlantic marine copepod biodiversity and climate. Science 296:1692-1694.

Belkin I. M. 2009. Rapid warming of large marine ecosystems. Progress in Oceanography 81:207-213.

Berbalk, D. 1996. The new Helsinki Convention and the joint comprehensive Environmental Action Programme. Pages 330335 in R. Platzöder and P. Verlaan, editors. The Baltic Sea: new developments in national policies and international cooperation. Kluwer Law International, The Hague, The Netherlands.

Berkenhagen J., R. Doring, H. O. Fock, M. H. F. Kloppmann, S. A. Pedersen, and T. Schulze. 2010. Decision bias in marine spatial planning of offshore wind farms: problems of singular versus cumulative assessments of economic impacts on fisheries. Marine Policy 34(3): 733-736.

Biggs R., M. Schluter, D. Biggs, E. L. Bohensky, S. BurnSilver, G. Cundill, V. Dakos, T. M. Daw, L. S. Evans, and K. Kotschy. 2012. Principles for enhancing the resilience of ecosystem services. Annual Review of Environment and Resources 37:421-448.

Brody, S. D. 2003. Measuring the effects of stakeholder participation on the quality of local plans based on the principles of collaborative ecosystem management. Journal of Planning Education and Research 22(4):407-419.

Bundesministerium für Umwelt, Naturschutz und Reaktorsicherheit (BMU). 2002. Strategie der Bundesregierung zur Windenergienutzung auf See. Federal Ministry for Environment, Nature Conservation and Nuclear Safety (BMU), Berlin, Germany.

Busch, M., A. Kannen, S. Garthe, and M. Jessopp. 2013. Consequences of a cumulative perspective on marine environmental impacts: offshore wind farming and seabirds at North Sea scale in context of the EU Marine Strategy Framework Directive. Ocean and Coastal Management 71: 213-224.

Carollo, C., and D. Reed. 2010. Ecosystem-based management institutional design: balance between federal, state, and local governments within the Gulf of Mexico Alliance. Marine Policy 34(1):178-181.

COM 2013. 2013. Proposal for a directive of the European Parliament and of the council establishing a framework for maritime spatial planning and integrated coastal management. 2013/0074 (COD), European Parliament, Strasbourg, France.
Commission of the European Communities (CEC). 2009. Reform of the common fisheries policy. Green Paper. Commission of the European Communities, Brussels, Belgium.

Cormier, R., A. Kannen, M. Elliott, P. Hall, and I. A. Davies, editors. 2013. Marine and coastal ecosystem-based risk management handbook. ICES Cooperative Research Report No. 317. International Council for the Exploration of the Sea, Copenhagen, Denmark.

Daskalov G. M., A. Grishin, S. Rodionov, and V. Mihneva. 2007. Trophic cascades triggered by overfishing reveal possible mechanisms of ecosystem regime shifts. Proceedings of National Academy of Sciences 104:10518-10523, http://dx.doi.org/10.1073/ pnas.0701100104

deYoung, B., M. Barange, G. Beaugrand, R. Harris, R. I. Perry, M. Scheffer, and F. Werner. 2008. Regime shifts in marine ecosystems: detection, prediction and management. Trends in Ecology and Evolution 23:402-409.

Diederich, S., G. J. E. E. Nehls, J. Beusekom, and K. Reise. 2004. Introduced Pacific oysters (Crassostrea gigas) in the northern Wadden Sea: invasion accelerated by warm summers? Helgoland Marine Research 59: 97-106.

Drinkwater, K. F. 2002. A review of the role of climate variability in the decline of northern cod. Pages 113-129 in N. A. McGinn, editor. Fisheries in a changing climate. American Fisheries Society, Bethesda, Maryland, USA.

Drinkwater, K. F., G. Beaugrand, M. Kaeriyama, S. Kim, G. Ottersen, R. I. Perry, H.-O. Pörtner, J. J. Polovina, and A. Takasuka. 2010. On the processes linking climate to ecosystem changes. Journal of Marine Systems 79: 374-388.

Farmer, A., L. Mee., O. Langmead, P. Cooper, A. Kannen, P. Kershaw, and V. Cherrier. 2012. The ecosystem approach in marine management. EU FP7 KNOWSEAS Project. European Union, Brussels, Belgium.

Fischer, C. 2011. Auf dem Weg zu einer integrierten Meerespolitik für die Europäische Union - Erfahrungen aus der transnationalen Zusammenarbeit am Beispiel der trilateralen Wattenmeerkooperation. Thesis, Leuphana University, Lueneburg, Germany.

Fitzmaurice, M. 1993. The New Helsinki Convention on the Protection of the Marine Environment of the Baltic Sea Area. Marine Pollution Bulletin 26(2):64-67.

Folke, C., S. Carpenter, B. Walker, M. Scheffer, T. Elmqvist, L. Gunderson, and C. S. Holling. 2004. Regime shifts, resilience, and biodiversity in ecosystem management. Annual Review of Ecology Evolution and Systematics 35:557-581.

Francis R. C., S. R. Hare, A. B. Hollowed, and W. S. Wooster.1998. Effects of interdecadal climate variability on the oceanic ecosystems of the NE Pacific. Fisheries Oceanography 7:1-21.

Garcia, S. M., and K. L. Cochrane. 2005. Ecosystem approach to fisheries: a review of implementation guidelines. ICES Journal of Marine Science 62(3):311-318. http://dx.doi.org/10.1016/j. icesjms.2004.12.003

Garthe S., and B. Mendel. 2010. Cumulative effects of anthropogenic activities on seabirds in the North Sea: 
methodology and first results. Pages 86-89 in M. Lange, B. Burkhard, S. Garthe, K. Gee, H. Lenhart, A. Kannen, and W. Windhorst, editors. Analysing coastal andmarine changes-offshore wind farming as a case study. Zukunft Kueste-Coastal Futures Synthesis Report. LOICZ R and S Report No. 36, Institute for Coastal Research, GKSS Research Center Geesthacht, Germany.

Gee K., A. Kannen, and B. Heinrichs. 2011. BaltSeaPlan vision 2030 for Baltic sea space. Department of Human Dimensions of Coastal Areas, Hamburg, Germany. [online] URL: http://www. baltseaplan.eu/index.php/BaltSeaPlan-Vision-2030;494/1.

Gilbert A. J., A. McQuatters-Gollop, O. Langmead, L. Mee, and J. Vermaat. 2014. Visions for the North Sea: the societal dilemma of specifying good environmental status. Ambio 5. http://dx.doi. org/10.1007/s13280-014-0536-5

Glaeser, B., K. Gee, A. Kannen, and H Sterr. 2005. Vorschläge für eine nationale IKZM-Strategie aus Sicht der Raumordnung. Pages 47-52 in Bundesministerium für Verkehr, Bau- und Wohnungswesen u. Bundesamt für Bauwesen und Raumordnung (Hrsg.) Nationale IKZM-Strategien - Europäische Perspektiven und Entwicklungstrends. Konferenzbericht zur Nationalen Konferenz, Berlin, Germany.

Gunderson, L., and C. S. Holling. 2002. Panarchy: understanding transformations in human and natural systems. Island Press, Washington, D.C., USA.

Hare, S. R., and N. J. Mantua. 2000. Empirical evidence for North Pacific regime shifts in 1977 and 1989. Progress in Oceanography 47: 103-145.

Helsinki Commission. 2013. Hot spots. [online] URL: http:// helcom.fi/action-areas/industrial-releases/main-pollution-sites-helcomhotspots

Heymans J. J., S. Guénette, and V. Christensen. 2007. Evaluating network analysis indicators of ecosystem status in the Gulf of Alaska. Ecosystems 10: 488-502.

Heymans, J. J., S. Mackinson, U. R. Sumaila, A. Dyck, and A. Little. 2011. The impact of subsidies on the ecological sustainability and future profits from North Sea fisheries. PLoS ONE 6(5): e20239. http://dx.doi.org/10.1371/journal.pone.0020239

Holling C. S. 1978. Adaptive environmental assessment and monitoring. Wiley, New York, New York, USA.

Hoyt, E. 2011. Marine protected areas for whales, dolphins and porpoises: a world handbook. Earthscan, London, UK.

Intergovernmental Panel on Climate Change (IPCC). 2000. Emission scenarios. a special report on Working Group III of the Intergovernmental Panel on Climate Change. IPPC, Cambridge, UK.

International Council for the Exploration of the Sea (ICES). 2012. Joint DFO/KnowSeas, and ICES Workshop on Quality Assurance in MSP (WKQAMSP). 28 February-1 March 2012, Dartmouth, Nova Scotia, Canada. ICES CM 2012/SSGHIE:02, ICES, Copenhagen, Denmark.

Kannen, A. 2014. Challenges for marine spatial planning in the context of multiple sea uses, policy arenas and actors based on experiences from the German North Sea. Regional Environmental Change 14:2139-2150.

Kannen, A., K. Ahrendt, A. Bruns, B. Burkhard, D. Diembeck, K. Gee, B. Glaeser, K. Licht-Eggert, T. Michler, O. MeyerEngelhard, C. Nunneri, S. Stragies, and W. Windhorst. 2009. Exploring the future of seas and coasts: scenarios within the joint research project Zukunft Küste - Coastal Futures. Pages 207-218 in E. Dahl, E. Moksness, and J. Støttrup, editors. Integrated coastal zone management. Wiley-Blackwell Publishing, London, UK.

Kannen, A., K. Gee, and A. Bruns. 2010. Governance aspects of offshore wind energy and maritime development. Pages 170-190 in M. Lange, B. Burkhard, S. Garthe, K. Gee, H. Lenhart, A. Kannen, and W. Windhorst. Analysing coastal and marine changes - offshore wind farming as a case study. Zukunft Kueste - Coastal Futures Synthesis Report. LOICZ R and S Report No. 36, Institute for Coastal Research, GKSS Research Center, Geesthacht, Germany.

Kannen, A., K. Gee, C. Fischer, R. Varjopuro, S. Knudsen, M. Fitzpatrick, C. O'Mahoney, T. Potts, K. Frangoudes, and J. L. de Vivero-Suarez. 2012. Assessment of environmental governance structures and specific case studies in Europe's regional seas. KnowSeas Deliverable 5.3, Institute for Coastal Research, GKSS Research Center, Geesthacht, Germany.

Kenny, A. J., H. R. Skjoldal, G. H. Engelhard, P. J. Kershaw, and J. B. Reid. 2009. An integrated approach for assessing the relative significance of human pressures and environmental forcing on the status of large marine ecosystems. Progress in Oceanography 81:132-148.

Kirby, R. R., G. Beaugrand, and J. A. Lindley. 2009. Synergistic effects of climate and fishing in a marine ecosystem. Ecosystems 12:548-561.

Koontz, T. M., and E. M. Johnson. 2004. One size does not fit all: matching breadth of stakeholder participation to watershed group accomplishments. Policy Sciences 37(2):185-204.

Langmead, O., A. McQuatters-Gollop, L. D. Mee, J. Friedrich, A. J. Gilbert, M.-T. Gomoiu, E. L. Jackson, S. Knudsen, G. Minicheva, and V. Todorova. 2009. Recovery or decline of the northwestern Black Sea: a societal choice revealed by socioecological modelling. Ecological Modelling 220(21):2927-2939.

Lees, K., S. Pitois , C. Scott, C. Frid, and S. Mackinson. 2006. Characterizing regime shifts in the marine environment. Fish and Fisheries 7:104-127.

Lindegren, M., V. Dakos, J. P. Gröger, A. Gårdmark, G. S. Kornilovs, S. Otto, and C. Möllmann. 2012. Early detection of ecosystem regime shifts: a multiple method evaluation for management application. PLoS ONE 7: e38410.

Llope, M., G. M. Daskalov, T. A. Rouyer, V. Mihneva, K-S. Chan, N. Alexander, A. N. Grishin, and N. C. Stenseth. 2011 Overfishing of top predators eroded the resilience of the Black Sea system regardless of the climate and anthropogenic conditions. Global Change Biology 17:1251-1265. http://dx.doi.org/10.1111/ j.1365-2486.2010.02331.x

Mee, L. D. 2006. Reviving dead zones. Scientific American, November: $78-85$. 
Mee, L. D., J. Friedrich, and M. T. Gomoiu. 2005. Restoring the Black Sea in times of uncertainty. Oceanography 18:32-43.

Mee, L. D. , R. Jefferson, D. d'A. Laffoley, and M. Elliott. 2008. How good is good? Human values and Europe's proposed marine strategy directive. Marine Pollution Bulletin 56(2):187-204.

Meier, H. E. M., H. Andersson, B. Arheimer, T. Blenckner, B. Chubarenko, C. Donnelly, K. Eilola, B. G. Gustafsson, A. Hansson, J. Havenhand, A. Höglund, I. Kuznetsov, B. R. MacKenzie, B. Müller-Karulis, T. Neumann, S. Niiranen, J. Piwowarczyk, U. Raudsepp, M. Reckermann, T. Ruoho-Airola, O. P. Savchuk, F. Schenk, S. Schimanke, G. Väli, J.-M. Weslawski, and E. Zorita. 2012. Comparing reconstructed past variations and future projections of the Baltic Sea ecosystem-first results from multi-model ensemble simulations. Environmental Research Letters 7: 034005. http://dx.doi.org/10.1088/1748-9326/7/3/034005

Millennium Ecosystem Assessment. 2003. Ecosystems and human well-being: a framework for assessment. Island Press, Washington, D.C., USA.

Niiranen, S., J. Yletyinen, M. T. Tomczak, T. Blenckner, O. Hjerne, B. R. MacKenzie, B. Müller-Karulis, T. Neumann, and H. E. M. Meier. 2013. Combined effects of global climate change and regional ecosystem drivers on an exploited marine food web. Global Change Biology 19:3327-3342.

Nyström, M., A. V. Norström, T. Blenckner, M. la Torre-Castro, J. S. Eklöf, C. Folke, H. Österblom, R. S. Steneck, M. Thyresson, and M. Troell. 2012. Confronting feedbacks of degraded marine ecosystems. Ecosystems 15:695-710.

OSPAR. 2010. Quality status report 2010. OSPAR Commission, London, UK.

Philippart, C. J. M., R. Anadon, R. Danovaro, J. W. Dippner, K. F. Drinkwater, S. J. Hawkins, T. Oguz, G. O’Sullivan, and P. C. Reid. 2011. Impacts of climate change on European marine ecosystems: observations, expectations and indicators. Journal of Experimental Marine Biology and Ecology 400:52-69.

Pomeroy, R., and F. Douvere. 2008. The engagement of stakeholders in the marine spatial planning process. Marine Policy 32(5):816-822.

Poutanen, E.-L. 1996. Activities of the Helsinki Commission. Pages 336-345 in R. Platzöder and P. Verlaan, editors. The Baltic Sea: new developments in national policies and international cooperation. Kluwer Law International, The Hague, The Netherlands.

Raskin, P., G. Gallopin, P. Gutman, A. Hammond, and R. Swart. 1998. Bending the curve: toward global sustainability. PoleStar Series Report, Environment Institute, Stockholm, Sweden.

Rotmans, J., C. Anastasi, M. v. Asselt, D. Rothman, J. Mellors, S. Greeuw, and C. v. Bers. 2001. VISIONS - the European scenario methodology. International Centre for Integrative Studies, Maastricht, The Netherlands.

Scheffer, M., S. Carpenter, J. A. Foley, C. Folke, and B. Walker. 2001. Catastrophic shifts in ecosystems. Nature 413:591-596.

Scheffer, M., J. Bascompte, W. A. Brock, V. Brovkin, S. R. Carpenter, V. Dakos, H. Held, E. H. van Nes, M. Rietkerk, and
G. Sugihara. 2009. Early-warning signals for critical transitions. Nature 461:53-59.

Shell International. 2002. Exploring the future: people and connections global scenarios to 2020. Global Business Environment (PXG). London, UK. [online] URL: https://www. pik-potsdam.de/avec/peyresq2005/talks/0921/leemans/literature/ shell global scenarios.pdf

Stenseth, N. C., and T. Rouyer. 2008. Ecology - Destabilized fish stocks. Nature 452:825-826.

Swaney, D. P., C. Humborg, K. Emeis, A. Kannen, W. Silvert, P. Tett, R. Pastres, C. Solidoro, M. Yamamuro, Y. Hénocque, and R. Nicholls. 2012. Five critical questions of scale for the coastal zone. Estuarine, Coastal and Shelf Science 96:9-21.

Wadden Sea Forum. 2006. Breaking the ice. Wilhelmshaven, Germany. [online] http://www.waddensea-forum.org/index.php/ strategy/breaking-the-ice

Walker, B., S. Carpenter, J. Anderies, N. Abel, G. S. Cumming, M. Janssen, L. Lebel, J. Norberg, G. D. Peterson, and R. Pritchard. 2002. Resilience management in social-ecological systems: a working hypothesis for a participatory approach. Ecology and Society 6(1): 14. [online] URL: http://www. ecologyandsociety.org/vol6/iss 1/art14/

Wiser, R., Z. Yang, M. Hand, O. Hohmeyer, D. Infield, P. H. Jensen, V. Nikolaev, M. O’Malley, M. Sinden, and A. Servos. 2011. Wind energy. Pages 535-607 in O. Edenhofer, R. Pichs-Madruga, Y. Sokona, K. Seyboth, P. Matschoss, S. Kadner, T. Zwickel, P. Eickemeier, G. Hansen, S. Schlömer, and C. von Stechow, editors. Renewable energy sources and climate change mitigation: special report of the Intergovernmental Panel on Climate Change. Cambridge University Press, Cambridge, UK, and New York, New York, USA.

World Business Council for Sustainable Development (WBCSD). 1997. Exploring sustainable development - global scenarios 2000 2050. World Business Council for Sustainable Development, London, UK.

Valman, M. 2013. Institutional stability and change in the Baltic Sea: 30 years of issues, crises and solutions. Marine Policy 38:54 64 .

van Tatenhove, J. P. M. 2013. How to turn the tide: developing legitimate marine governance arrangements at the level of the regional seas. Ocean and Coastal Management 75:43-52. 